\title{
Diabetes Mellitus Increases the Risk of Bladder Cancer: An Updated Meta-Analysis of Observational Studies
}

\author{
Hong Fang, MD, Baodong Yao, MD, Yujie Yan, MD, Huilin Xu, MD, Yinan Liu, MD, \\ Hongmei Tang, MD, Jie Zhou, MD, Lili Cao, MD, Weijie Wang, MD, Jinling Zhang, MD, \\ Liyun Zhao, MD, Xi Chen, MD, Fen Zhang, MD, and Yanping Zhao, MD
}

\begin{abstract}
Background: Increasing evidence suggests that diabetes mellitus (DM) may be associated with an increased risk of bladder cancer. We performed an updated meta-analysis to examine the association between DM and risk of bladder cancer.

Materials and Methods: We systematically searched the EMBASE and Medline (PubMed) databases (from inception through February 1, 2013) and reviewed the reference lists of relevant publications to search for additional studies. Summary relative risks (RRs) with 95\% confidence intervals (CIs) were calculated with random-effects models.

Results: In total, 10 case-control and 14 cohort studies met the inclusion criteria. Analysis of all studies showed that DM was associated with an increased risk of bladder cancer (RR 1.30,95\% CI 1.18-1.43). There was heterogeneity among studies ( $P_{\text {heterogeneity }}<0.001, I^{2}=81.5 \%$ ). Cohort studies showed a lower risk (RR 1.23, 95\% CI 1.09-1.37) than case-control studies (odds ratio $1.46,95 \%$ CI 1.20-1.78). The positive association was significant only in women (RR 1.23, 95\% CI 1.02-1.49), but not in men (RR 1.07, 95\% CI 0.97-1.18). The combined RRs remained unchanged before and after the studies on type 1 diabetes were excluded from analysis. The association between DM and bladder cancer risk did not differ significantly by methods of DM ascertainment. The combined RRs were 1.17 (95\% CI 1.03-1.34), 1.34 (95\% CI 1.19-1.51), and 1.57 (95\% CI 0.96-2.55), respectively, when restricting the analysis to the studies accounting for body mass index, cigarette smoking, or glucose-lowering drug use. Conclusions: This meta-analysis indicates a positive association between DM and risk of bladder cancer. Further studies are warranted to determine whether DM prevention and control can reduce risk of bladder cancer.
\end{abstract}

\section{Introduction}

D IABETES MELlitus (DM) HAS INCREASED worldwide in recent decades with changes in lifestyle and population aging. It is estimated that around the world more than 366 million people had DM in 2011, and the number is predicted to reach 552 million by $2030 .{ }^{1} \mathrm{DM}$ is associated with long-term complications that include cardiovascular disease, retinopathy, neuropathy, and nephropathy. Additionally, DM has been implicated as a risk factor for certain malignancies, including cancers of the colon/rectum, breast, and pancreas. ${ }^{2-4}$

Bladder cancer is the sixth most common cancer in the United States. ${ }^{5}$ Several potential risk factors for bladder cancer have been established, including tobacco smoking, drinking water contaminants such as chlorinated byproducts and arsenic, and use of pioglitazone..$^{6-8}$ A meta-analysis of epidemiologic studies suggested an increased risk of bladder cancer in relation to DM. ${ }^{9}$ Since then, many new epidemiological studies have examined the association of DM with the risk of bladder cancer, but results were inconsistent. ${ }^{10,11} \mathrm{Zhu}$ et al. ${ }^{12}$ published another relevant study, and this meta-analysis focused on co- hort studies. Because of a lack of primary studies, there were only a few subgroup analyses. Although prospective cohort studies are expected to have eliminated the selection bias and recall bias that could be of concern in retrospective case-control studies, the consistent results from both cohort and case-control studies should be considered before establishing a causal relationship according to the criteria of Hill. ${ }^{13}$ Considering that long-term randomized trials are impossible to implement on a practical basis, case-control and cohort studies are the best evidence available to assess the association between DM and risk of bladder cancer; thus we included all recently published case-control and cohort studies in this meta-analysis.

\section{Materials and Methods}

\section{Searching}

We systematically identified studies through searching the EMBASE and Medline (PubMed) databases from their inception to February 1, 2013, for human studies of DM and bladder cancer in any language. The overall search strategy included the search term "diabetes" combined with "bladder cancer" or

Shanghai Minhang Center for Disease Control and Prevention, Shanghai, People's Republic of China. 
"bladder neoplasm." We also manually reviewed the reference lists of relevant publications to search for additional studies.

\section{Inclusion and exclusion criteria}

All studies were included, if they met the following criteria: (1) evaluation of DM and bladder cancer risk; (2) presenting original data from case-control or cohort studies; and (3) providing relative risk (RR) estimates with confidence intervals (CIs) or enough data to calculate them. Major exclusion criteria were (1) studies on mortality rates from bladder cancer or (2) studies that include evaluation of DM and bladder cancer risk with standardized incidence ratios. If the publications were duplicated or shared in more than one study, either the most recent publications or the publications with multivariate-adjusted estimates were included.

\section{Data abstraction}

Two investigators independently extracted the data and reached consensus on all items. The following information was sought from each study: the first author's last name, year of the publication, country of study location, study design, type of DM (DM assessment), numbers of cases and controls (in case-control studies), type of control (in case-control studies), number of exposed and unexposed (in cohort studies), follow-up period (for cohort studies), risk of estimates with their corresponding CIs for bladder cancer associated with DM, and confounders considered. From each study, we extracted the risk estimate that was adjusted for the greatest number of potential confounders.

\section{Statistical analysis}

Major outcome variables were quantitative measures of the association between DM and bladder cancer risk. Because bladder cancer is a rare disease, odds ratios (ORs) from casecontrol studies and RRs from cohort studies produce comparable estimates. Summary RRs and their 95\% CIs were calculated with the method of DerSimonian and Laird ${ }^{14}$ by the use of the assumptions of a random-effects model that considers both within-study and between-study variation. Separate and combined analyses were carried out for casecontrol and cohort studies. We examined possible heterogeneity in results across studies using the $Q$ and $I^{2}$ statistics. ${ }^{15}$ For the $Q$ statistic, a $P$ value of $<0.10$ was considered representative of statistically significant heterogeneity. $I^{2}$ is the proportion of total variation contributed by between-study variation. ${ }^{15}$ The "leave one out" sensitive analysis ${ }^{16}$ was carried out using $I^{2}>50 \%$ as the criterion to evaluate the key studies with substantial impact on between-study heterogeneity. In an attempt to evaluate the possible publication bias, Egger's test (linear regression method) ${ }^{17}$ and Begg's test (rank correlation method) ${ }^{18}$ were used, and a $P$ value of $<0.05$ was considered representative of significant statistical publication bias. All statistical analyses were performed with STATA version 9.2 software (StataCorp, College Station, TX).

\section{Results}

\section{Description of studies}

Figure 1 shows a flow diagram of how we selected relevant studies. We identified 26 potentially relevant stud-
1214 citations screened

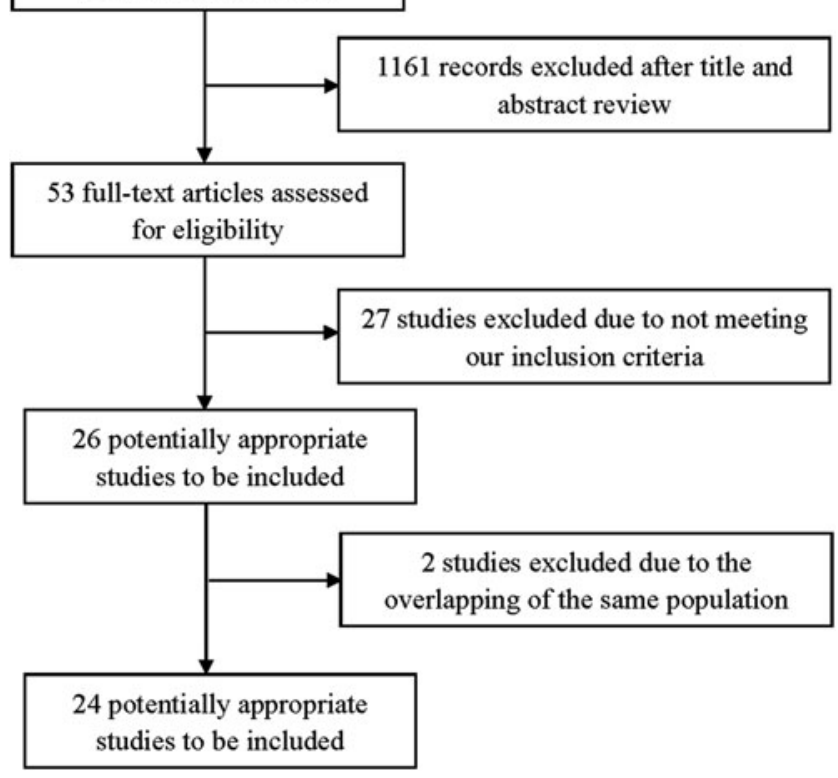

FIG. 1. Selection of studies for the meta-analysis.

ies. $^{3,4,10,11,19-40}$ Two studies were excluded because of overlapping publications from the same study population. $^{39,40}$ Thus, a total of 24 case-control and cohort studies met our inclusion criteria (Tables 1 and 2). Among these 24 studies, 10 were case-control studies, and 14 were cohort studies. All included studies were published between 1984 and 2013, of which $71 \%(n=17)$ were published in 2006 or more recently. Six studies were conducted in Europe, six in Asia, and 12 in North America. The study population in 17 studies consisted of both sexes, six studies included men only, and one study included women only. In total, 9,752,495 participants were included in these 24 studies. Because no detailed number of cases was available in two cohort studies, ${ }^{4,10}$ 40,410 bladder cancer cases were included among the 22 reported studies.

\section{DM and bladder cancer risk}

Ten case-control studies ${ }^{3,19-27}$ and 14 cohort studies $^{4,10,11,28-38}$ were included in the meta-analysis. Analysis of all studies showed that, compared with individuals without DM, those with DM had a statistically significant increased risk of bladder cancer (RR 1.30, 95\% CI 1.18-1.43) (Fig. 2). There was statistically significant heterogeneity among studies $\left(Q=129.96, P_{\text {heterogeneity }}<0.001, I^{2}=81.5 \%\right)$. The key contributors of the articles to the between-study heterogeneity assessed by the "leave one out" sensitive analysis were three studies. ${ }^{23,32,34}$ After exclusion of the above-mentioned articles that were the key contributors to between-study heterogeneity, the meta-analysis also showed a significant association of DM and the risk of bladder cancer (RR 1.24, 95\% CI 1.15-1.34; $P_{\text {heterogeneity }}=0.011, I^{2}=45.7 \%$ ).

In the subgroup analyses (Table 3), a positive association was observed only in women (RR 1.23, 95\% CI 1.02-1.49) but not in men (RR 1.07, 95\% CI 0.97-1.18). Analyses stratified by study design showed that DM was associated with a greater risk of bladder cancer in case-control studies (RR 1.46, 95\% CI 
Table 1. Main Characteristics of Cohort Studies Included in the Meta-Analysis, Arranged by Year of Publication

\begin{tabular}{|c|c|c|c|c|c|c|c|c|}
\hline $\begin{array}{l}\text { Reference } \\
\text { (year) }\end{array}$ & $\begin{array}{c}\text { Country } \\
\text { (study period) }\end{array}$ & Sex & $\begin{array}{l}\text { Age } \\
\text { (years) }\end{array}$ & Cases & $\begin{array}{l}\text { Years of } \\
\text { follow-up }\end{array}$ & Cohort size & DM assessment & Adjustments \\
\hline $\begin{array}{l}\text { Jee et al. }{ }^{4} \\
\quad(2005)\end{array}$ & $\begin{array}{c}\text { Korea } \\
(1992-2002)\end{array}$ & M & $30-95$ & NA & 10 & 829,770 & $\begin{array}{l}\text { Blood glucose } \\
\text { level or } \\
\text { medication } \\
\text { use (type 2) }\end{array}$ & Age, smoking, and alcohol \\
\hline $\begin{array}{l}\text { Inoue et al. } \\
\quad(2006)\end{array}$ & $\begin{array}{c}\text { Japan } \\
(1990-2003)\end{array}$ & $\mathrm{M} / \mathrm{F}$ & $40-79$ & $105 \mathrm{M} / 30 \mathrm{~F}$ & $\begin{array}{c}10.7 \\
\text { (mean) }\end{array}$ & $\begin{array}{c}46,548 \mathrm{M} / \\
51,223 \mathrm{~F}\end{array}$ & $\begin{array}{l}\text { Self-report } \\
\text { (type } 1 \text { and } 2 \text { ) }\end{array}$ & $\begin{array}{l}\text { Age, study area, history of } \\
\text { cerebrovascular disease, } \\
\text { history of ischemic heart } \\
\text { disease, smoking, ethanol } \\
\text { intake, BMI, leisure-time } \\
\text { physical activity, green } \\
\text { vegetable intake, and } \\
\text { coffee intake }\end{array}$ \\
\hline $\begin{array}{l}\text { Rapp et al. } \\
\text { (2006) }\end{array}$ & $\begin{array}{c}\text { Austria } \\
(1988-2001)\end{array}$ & $\mathrm{M}$ & $35-54$ & $\begin{array}{c}11 \\
(\mathrm{ICD}-9)\end{array}$ & $\begin{array}{c}8.4 \\
\text { (mean) }\end{array}$ & 63,585 & $\begin{array}{l}\text { Glucose levels } \\
\text { (NA) }\end{array}$ & $\begin{array}{l}\text { Age, smoking, occupational } \\
\text { group, and BMI }\end{array}$ \\
\hline $\begin{array}{l}\text { Khan et al. } \\
\text { (2006) }\end{array}$ & $\underset{(1988-1999)}{\text { Japan }}$ & M & $40-79$ & $\begin{array}{c}60 \\
(\mathrm{ICD}-10)\end{array}$ & 11 & 23,378 & $\begin{array}{l}\text { Self-report } \\
\text { (NA) }\end{array}$ & $\begin{array}{l}\text { Age, smoking, BMI, and } \\
\text { alcohol }\end{array}$ \\
\hline $\begin{array}{l}\text { Larsson et al. }{ }^{11} \\
\quad(2008)\end{array}$ & $\begin{array}{c}\text { Sweden } \\
(1998-2007)\end{array}$ & $\mathrm{M}$ & $45-79$ & $\begin{array}{c}414 \\
(\mathrm{ICD}-\mathrm{O}-2)\end{array}$ & $\begin{array}{c}9.3 \\
\text { (mean) }\end{array}$ & 45,906 & $\begin{array}{l}\text { Self-report } \\
\text { (NA) }\end{array}$ & $\begin{array}{l}\text { Age, education, smoking } \\
\text { status, and pack-years } \\
\text { of smoking }\end{array}$ \\
\hline $\begin{array}{l}\text { Ogunleye } \\
\text { et al. }{ }^{31}(2009)\end{array}$ & $\begin{array}{c}\text { Scotland, } \\
\text { United Kingdom } \\
(1993-2004)\end{array}$ & $\mathrm{M} / \mathrm{F}$ & All ages & $\begin{array}{c}68 \\
(\mathrm{ICD}-10)\end{array}$ & $\begin{array}{l}\text { 1,417 days } \\
\text { (mean) }\end{array}$ & 28,731 & $\begin{array}{c}\text { Diagnosis } \\
\text { of type } 2 \text { DM }\end{array}$ & Age, sex, and deprivation \\
\hline $\begin{array}{l}\text { Yood et al. }{ }^{32} \\
\quad(2009)\end{array}$ & $\begin{array}{l}\text { United States } \\
(2000-2004)\end{array}$ & $\mathrm{M} / \mathrm{F}$ & $\begin{array}{l}18 \text { years } \\
\text { or older }\end{array}$ & $\begin{array}{l}243 \\
\text { (ICD-9; } \\
\text { procedure } \\
\text { codes; } \\
\text { treatment } \\
\text { codes) }\end{array}$ & 4 & 442,512 & $\begin{array}{l}\text { Diagnosis } \\
\text { of type } 2 \text { DM } \\
\text { medication } \\
\text { use }\end{array}$ & $\begin{array}{l}\text { Age, gender, schistosomiasis, } \\
\text { and pelvic radiation }\end{array}$ \\
\hline $\begin{array}{l}\text { Tseng }^{10} \\
\quad(2011)\end{array}$ & $\begin{array}{c}\text { Taiwan } \\
(2003-2005)\end{array}$ & $\mathrm{M} / \mathrm{F}$ & All ages & $\begin{array}{c}\text { NA } \\
\text { (ICD-9: 188) }\end{array}$ & 3 & 998,947 & $\begin{array}{l}\text { Medical } \\
\text { records } \\
\text { (type 2) }\end{array}$ & $\begin{array}{l}\text { Age, sex, nephropathy, } \\
\text { urinary tract diseases, } \\
\text { comorbidities, glucose- } \\
\text { lowering drugs, living } \\
\text { region, and occupation }\end{array}$ \\
\hline $\begin{array}{l}\text { Woolcott } \\
\text { et al. }^{33}(2011)\end{array}$ & $\begin{array}{l}\text { United States } \\
(1993-2004)\end{array}$ & $\mathrm{M} / \mathrm{F}$ & $45-75$ & $\begin{array}{c}818 \\
(\mathrm{ICD}-\mathrm{O}-2: \mathrm{C}-67)\end{array}$ & $\begin{array}{c}10.7 \\
\text { (mean) }\end{array}$ & 185,816 & $\begin{array}{l}\text { Self-report } \\
\text { (NA) }\end{array}$ & $\begin{array}{l}\text { Age, ethnicity, sex, smoking, } \\
\text { and employment }\end{array}$ \\
\hline $\begin{array}{l}\text { Atchison } \\
\text { et al. }^{34}(2011)\end{array}$ & $\begin{array}{l}\text { United States } \\
(1969-1996)\end{array}$ & $\mathrm{M}$ & $18-100$ & $\begin{array}{l}\text { 19,300 } \\
\text { (ICD A-8 and } \\
\text { ICD 9-CM:188) }\end{array}$ & $\begin{array}{l}10.5 \text { vs. } 11.9 \\
\text { (mean; } \\
\text { men with } \\
\text { vs. without } \\
\text { diabetes) }\end{array}$ & $4,501,578$ & $\begin{array}{l}\text { Diagnosis } \\
\text { of DM (NA) }\end{array}$ & $\begin{array}{l}\text { Age, time, latency, race and } \\
\text { number of visits, diagnoses } \\
\text { of alcohol-related conditions, } \\
\text { obesity and chronic } \\
\text { obstructive pulmonary } \\
\text { disease }\end{array}$ \\
\hline $\begin{array}{l}\text { Lo et al. } \\
\qquad(2012)\end{array}$ & $\begin{array}{c}\text { Taiwan } \\
(1996-2009)\end{array}$ & $\mathrm{M} / \mathrm{F}$ & NA & $\begin{array}{c}4311 \\
(\mathrm{ICD}-9-\mathrm{CM}: \\
188.0)\end{array}$ & 14 & $1,790,868$ & $\begin{array}{l}\text { Medical } \\
\text { records } \\
\text { (type 2) }\end{array}$ & $\begin{array}{l}\text { Sex, age, urbanization, } \\
\text { hypertension, and } \\
\text { hyperlipidemia }\end{array}$ \\
\hline $\begin{array}{l}\text { Newton et al. } \\
\text { (2012) }\end{array}$ & $\begin{array}{l}\text { United States } \\
(1992-2007)\end{array}$ & $\mathrm{M} / \mathrm{F}$ & NA & 1,852 (NA) & 15 & 172,791 & $\begin{array}{l}\text { Self-report } \\
\text { (exclusion } \\
\text { if diagnosis } \\
<30 \text { years) }\end{array}$ & $\begin{array}{l}\text { Age, sex, race, BMI, smoking } \\
\text { status, education, and alcohol } \\
\text { intake }\end{array}$ \\
\hline $\begin{array}{l}\text { Prizment } \\
\text { et al. }^{37}(2013)\end{array}$ & $\begin{array}{l}\text { United States } \\
(1986-2010)\end{array}$ & $\mathrm{F}$ & $55-69$ & $\begin{array}{c}277 \\
\text { (ICD-O-3: } \\
\text { C670-679, 8120, } \\
8122,8123 \\
\text { or } 8130)\end{array}$ & 24 & 37,327 & $\begin{array}{l}\text { Self-report } \\
\text { (exclusion } \\
\text { if diagnosis } \\
<30 \text { years) }\end{array}$ & $\begin{array}{l}\text { Age, BMI, WHR, education, } \\
\text { smoking status, pack-years } \\
\text { of smoking, occupation, } \\
\text { marital status, physical } \\
\text { activity, and alcohol use }\end{array}$ \\
\hline $\begin{array}{l}\text { Lai et al. }^{38} \\
\qquad(2013)\end{array}$ & $\begin{array}{c}\text { United States } \\
(1995-2006)\end{array}$ & $\mathrm{M} / \mathrm{F}$ & $50-71$ & 4,331 (NA) & 11 & 494,867 & $\begin{array}{l}\text { Self-report } \\
\text { (type } 1 \\
\text { and 2) }\end{array}$ & $\begin{array}{l}\text { Age, sex, BMI, race/ethnicity, } \\
\text { education, marital status, } \\
\text { family history of cancer, } \\
\text { self-reported health status, } \\
\text { intake of red meat, white } \\
\text { meat, fruits, vegetables, } \\
\text { alcohol, and coffee, vigorous } \\
\text { physical activity, physical } \\
\text { activity at work, cigarette } \\
\text { smoking, multivitamin } \\
\text { use, and, for female-specific } \\
\text { cancers, postmenopausal } \\
\text { hormone therapy use }\end{array}$ \\
\hline
\end{tabular}


Table 2. Main Characteristics of Case-Control Studies Included in the Meta-Analysis, Arranged by Year of Publication

\begin{tabular}{|c|c|c|c|c|c|c|c|}
\hline $\begin{array}{l}\text { Reference } \\
\text { (year) }\end{array}$ & Country & Sex & $\begin{array}{l}\text { Age } \\
\text { (years) }\end{array}$ & Cases & $\begin{array}{c}\text { Controls } \\
\text { (selection method) }\end{array}$ & DM assessment & Adjustments \\
\hline $\begin{array}{l}\text { Kantor et al. }{ }^{19} \\
\text { (1984) }\end{array}$ & United States & $\mathrm{M} / \mathrm{F}$ & $21-84$ & 2,982 & $5,782(\mathrm{P})$ & $\begin{array}{l}\text { Self-report } \\
\text { (type } 1 \text { and 2) }\end{array}$ & $\begin{array}{l}\text { Age, sex, race, and } \\
\text { smoking }\end{array}$ \\
\hline $\begin{array}{l}\text { O'Mara et al. }^{\prime 20} \\
\text { (1985) }\end{array}$ & United States & $\mathrm{M} / \mathrm{F}$ & $30-89$ & 527 & $4,620(\mathrm{H})^{\mathrm{a}}$ & $\begin{array}{l}\text { Self-report } \\
\text { (type } 1 \text { and 2) }\end{array}$ & Age \\
\hline $\begin{array}{l}\text { Risch et al. } \\
\quad(1988)\end{array}$ & Canada & $\mathrm{M} / \mathrm{F}$ & $35-79$ & 826 & $792(\mathrm{P})$ & $\begin{array}{l}\text { Self-report } \\
\text { (type 2) }\end{array}$ & $\begin{array}{l}\text { Age, sex, place of } \\
\text { residence, and } \\
\text { smoking }\end{array}$ \\
\hline $\begin{array}{l}\text { La Vecchia et al. } \\
\text { (1994) }\end{array}$ & Italy & $\mathrm{M} / \mathrm{F}$ & $<75$ & 431 & $7,834(\mathrm{H})$ & $\begin{array}{l}\text { Self-report } \\
\text { (type } 1 \text { and 2) }\end{array}$ & Age and sex \\
\hline $\begin{array}{l}\text { Kravchick et al. } \\
\quad(2001)\end{array}$ & Israel & $\mathrm{M} / \mathrm{F}$ & $41-90$ & 252 & $549(\mathrm{H})$ & $\begin{array}{l}\text { Self-report } \\
\text { (type } 1 \text { and 2) }\end{array}$ & Age, sex, and smoking \\
\hline$\underset{(2003)}{\mathrm{Ng} \mathrm{et} \mathrm{al.}}$ & United Kingdom & $\mathrm{M} / \mathrm{F}$ & $>60$ & 125 & $80(\mathrm{H})$ & $\begin{array}{l}\text { Medical records } \\
\text { (types } 1 \text { and } 2 \text { ) }\end{array}$ & Age and smoking \\
\hline $\begin{array}{l}\text { Rousseau et al. }{ }^{25} \\
\text { (2006) }\end{array}$ & Canada & M & $35-70$ & 437 & $509(\mathrm{P})$ & $\begin{array}{l}\text { Self-report } \\
\text { (type } 1 \text { and 2) }\end{array}$ & $\begin{array}{l}\text { Age, family income, } \\
\text { years of schooling, } \\
\text { ethnicity, smoking, } \\
\text { proxy status, BMI, } \\
\beta \text {-carotene consumption, } \\
\text { coffee consumption, } \\
\text { and occupational } \\
\text { exposure to aromatic } \\
\text { amines }\end{array}$ \\
\hline $\begin{array}{l}\text { Jiang et al. }{ }^{26} \\
\text { (2009) }\end{array}$ & United States & $\mathrm{M} / \mathrm{F}$ & $25-64$ & 1,586 & $1,586(\mathrm{P})$ & $\begin{array}{l}\text { Self-report } \\
\text { (type } 1 \text { and } 2 \text { ) }\end{array}$ & $\begin{array}{l}\text { Age, sex, smoking, } \\
\text { education, NSAID } \\
\text { pills, intake of carotenoids, } \\
\text { and duration of } \\
\text { employment as a } \\
\text { hairdresser/barber }\end{array}$ \\
\hline $\begin{array}{l}\text { MacKenzie } \\
\text { et al. }{ }^{27}(2011)\end{array}$ & United States & $\mathrm{M} / \mathrm{F}$ & $25-74$ & 331 & $263(\mathrm{P})$ & $\begin{array}{c}\text { Self-report } \\
\text { (type } 1 \text { and 2) }\end{array}$ & $\begin{array}{l}\text { Age, gender, smoking, } \\
\text { BMI, and UTI }\end{array}$ \\
\hline $\begin{array}{l}\text { Attner et al. } \\
(2012)^{\mathrm{c}}\end{array}$ & Sweden & $\mathrm{M} / \mathrm{F}$ & NA & 1,093 & $8,043(\mathrm{P})$ & $\begin{array}{l}\text { Medical records } \\
\text { (types } 1 \text { and } 2 \text { ) }\end{array}$ & $\begin{array}{l}\text { Age, gender, obesity, and } \\
\text { abnormal blood lipids }\end{array}$ \\
\hline
\end{tabular}

${ }^{\mathrm{a}}$ The relative risk (and its 95\% confidence interval) was derived by pooling the sex-specific relative risks, weighted by the inverse of their variance. The confidence interval was estimated from data provided in the article.

${ }^{b}$ Onset of diabetes after age 20 years.

${ }^{c}$ Multivariate analysis for the time interval 90-1,460 days prior to the diagnosis of cancer.

BMI, body mass index; F, female; H, hospital-based; M, male; NA, not available; NSAID, nonsteroidal anti-inflammatory drug; P, population-based; UTI, urinary tract infections.

1.20-1.78) than in cohort studies (RR 1.23, 95\% CI 1.09-1.37; $n=14)$. In cohort studies, DM was not associated with the risk of bladder cancer in studies with follow-up time of below 10 years (RR 1.30, 95\% CI 0.91-1.47), ${ }^{10,11,29,31,32}$ whereas a positive association was observed in the studies with follow-up time of 10 years or above (RR 1.17, 95\% CI 1.04-1.31).,28,30,33-38 A significant positive association was consistently observed in studies conducted in North America ${ }^{19-21,25-27,32-34,36-38}$ and Asia, $4,10,23,28,30,35$ but a null association was obtained from the studies conducted in Europe (RR 1.11, 95\% CI 0.841.48). $3,11,22,24,29,31$ The summary estimate was slightly higher for studies published before 2005 (RR 1.39, 95\% CI 1.12$1.73)^{4,19-24}$ than those after 2005 (RR 1.27, 95\% CI 1.131.42). ${ }^{3,10,11,25-38}$ No difference was observed between the studies with self-reported DM and those with DM identified by medical records or medication use. The summary estimate was also similar for studies that included type 2 DM only (RR $1.34,95 \%$ CI 1.14-1.58) ${ }^{4,10,21,31,32,35-37}$ and for those including both type 1 and type 2 DM (RR 1.37, 95\% CI 1.16$1.63), 3,19,20,22-28,38$ but no association was found for studies in which the type of DM was not available (RR 1.10, 95\% CI 0.911.33). ${ }^{11,29,30,33,34}$
Obesity, cigarette smoking, and glucose-lowering drugs or insulin use are potential confounders for the association between DM and bladder cancer. When we restricted the analysis to the studies that had adjusted for body mass index (BMI) or obesity, $3,25,27-30,34,36-38$ the RR was 1.17 (95\% CI 1.031.34). Among the 16 studies that controlled for cigarette smoking, ${ }^{4,11,19,21,23-30,33,36-38}$ the combined RR was 1.34 (95\% CI 1.19-1.51). There were three studies ${ }^{10,21,27}$ that had adjusted for glucose-lowering drugs, and the combined RR was 1.57 (95\% CI 0.96-2.55). Three studies ${ }^{10,27,36}$ comparing those with DM who used insulin with those without DM yielded a combined RR of 1.52 (95\% CI 1.00-2.32).

In total, four studies ${ }^{10,27,36,37}$ examined the association of bladder cancer risk with the duration of DM. The combined RRs appeared higher among patients with a shorter duration of DM. Compared with subjects without DM, the combined RR was 1.25 (95\% CI 0.93-1.68; $\left.P_{\text {heterogeneity }}=0.118, I^{2}=49.0 \%\right)$ for patients diagnosed with DM more than 10 years, 1.38 (95\% CI 0.74-2.59; $\left.P_{\text {heterogeneity }}=0.048, I^{2}=74.4 \%\right)$ for those with DM duration of 5-10 years, and 1.52 (95\% CI 1.09-2.12; $P_{\text {heterogeneity }}=0.004, I^{2}=71.3 \%$ ) for those with DM duration of 5 years or less. The combined RR of three studies evaluating 


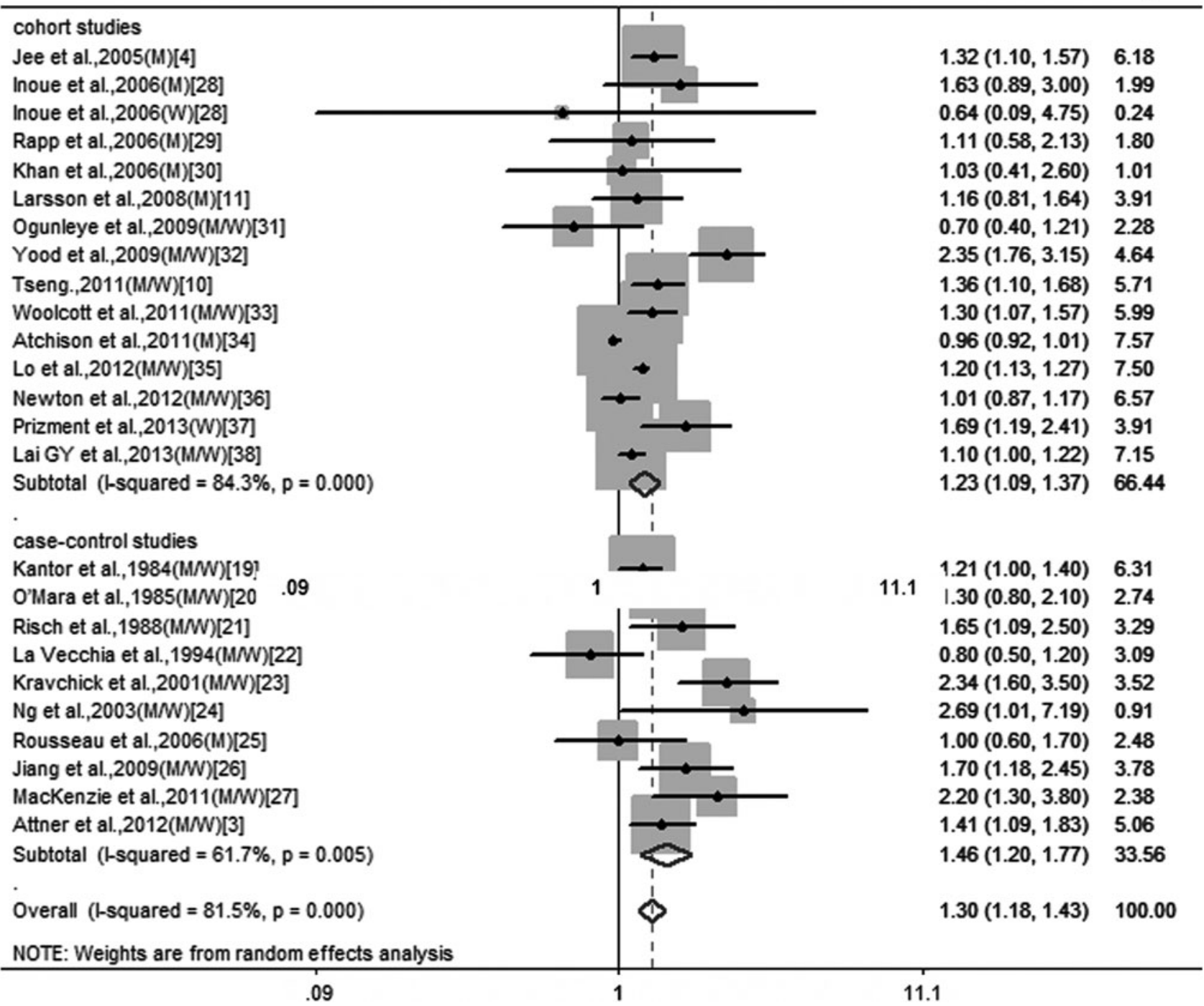

FIG. 2. Relative risks (RRs) for the association between diabetes mellitus and bladder cancer in case-control and cohort studies. The diamond denotes the pooled RR. Shaded rectangles indicate the RR in each study, with sizes inversely proportional to the SE of the RR. Horizontal lines indicate the $95 \%$ confidence interval (CI). M, men; W, women.

the association between DM and the risk of invasive bladder cancer was 1.13 (95\% CI 0.93-1.39). ${ }^{11,27,36}$

\section{Publication bias}

The funnel plot (Fig. 3) showed some asymmetry reflecting the relative absence of studies with small sample sizes and inverse associations. Egger's test for publication bias was statistically significant $(P=0.008)$. However, Begg's test for publication bias was not statistically significant $(P=0.498)$.

\section{Discussion}

The findings of this meta-analysis of 10 case-control studies and 14 cohort studies indicate that DM is associated with a moderate increased risk of bladder cancer. This association remained unchanged when subjects with confirmed type 2 DM included. Our meta-analysis showed significant between- study heterogeneity, and then we carried out the "leave one out" sensitive analysis using $I^{2}>50 \%$ as the criterion. After exclusion of three articles ${ }^{23,32,34}$ that were key contributors to the between-study heterogeneity, we found no significantly different RR. The summary RR was slightly higher for casecontrol studies than that for cohort studies, as well as for North American and Asian studies compared with that for European studies.

We included several newly published case-control and cohort studies in this updated meta-analysis, which allowed for a more detailed and accurate risk estimation than that of prior meta-analyses. The association between blood glucose levels and bladder cancer was stronger in women than in men in a very large cohort. ${ }^{41}$ Likewise, the positive association was only observed in women in our analysis, and that was different from results of the previous meta-analysis. ${ }^{12}$ The subgroup analysis of women was based on only five studies. Therefore, it is premature to conclude that the positive 
Table 3. Meta-Analysis for Diabetes Mellitus and Risk of Bladder Cancer

\begin{tabular}{|c|c|c|c|c|}
\hline \multirow[b]{2}{*}{ Analysis } & \multirow[b]{2}{*}{ Number of studies } & \multirow{2}{*}{$\begin{array}{c}\text { Summary estimate } \\
(95 \% \mathrm{CI})\end{array}$} & \multicolumn{2}{|c|}{ Heterogeneity } \\
\hline & & & $\mathrm{I}^{2}(\%)$ & $\mathrm{P}$ value \\
\hline All studies & 24 & $1.30(1.18-1.43)$ & 81.5 & $<0.001$ \\
\hline \multicolumn{5}{|l|}{ Gender } \\
\hline Male & 10 & 1.07 (0.97-1.18) & 53.6 & 0.022 \\
\hline Female & 5 & 1.23 (1.02-1.49) & 28.1 & 0.234 \\
\hline \multicolumn{5}{|l|}{ Study design } \\
\hline Cohort studies & 14 & 1.23 (1.09-1.37) & 84.3 & $<0.001$ \\
\hline Case-control studies & 10 & $1.46(1.20-1.78)$ & 61.7 & $<0.001$ \\
\hline \multicolumn{5}{|l|}{ Duration of follow-up ${ }^{a}$} \\
\hline$<10$ years & 5 & $1.30(0.91-1.47)$ & 79.7 & 0.001 \\
\hline$\geq 10$ years & 9 & 1.17 (1.04-1.31) & 83.4 & $<0.001$ \\
\hline \multicolumn{5}{|l|}{ Study areas } \\
\hline Asia & 6 & 1.37 (1.17-1.60) & 56.8 & 0.031 \\
\hline Europe & 6 & $1.11(0.84-1.48)$ & 54.5 & 0.052 \\
\hline North America & 12 & 1.33 (1.15-1.54) & 86.0 & $<0.001$ \\
\hline \multicolumn{5}{|l|}{ Year of publication } \\
\hline$\leq 2005$ & 7 & 1.39 (1.12-1.73) & 65.5 & 0.008 \\
\hline$>2006$ & 17 & $1.27(1.13-1.42)$ & 83.1 & $<0.001$ \\
\hline \multicolumn{5}{|l|}{ DM ascertainment } \\
\hline MR, MU, or blood level & 9 & $1.29(1.09-1.52)$ & 90.4 & $<0.001$ \\
\hline Self-report & 15 & $1.30(1.15-1.48)$ & 62.1 & 0.001 \\
\hline \multicolumn{5}{|l|}{ Type of DM } \\
\hline Only type 2 & 8 & $1.34(1.14-1.58)$ & 81.1 & $<0.001$ \\
\hline Type 1 and type 2 & 11 & 1.37 (1.16-1.63) & 65.4 & 0.001 \\
\hline Type not reported & 5 & $1.10(0.91-1.33)$ & 60.5 & 0.038 \\
\hline \multicolumn{5}{|c|}{ Adjustment for BMI or obesity } \\
\hline Yes & 10 & $1.17(1.03-1.34)$ & 69.4 & $<0.001$ \\
\hline No & 14 & $1.37(1.21-1.56)$ & 71.9 & $<0.001$ \\
\hline \multicolumn{5}{|c|}{ Adjustment for cigarette smoking } \\
\hline Yes & 16 & $1.34(1.19-1.51)$ & 59.9 & 0.001 \\
\hline No & 8 & $1.22(1.03-1.45)$ & 91.0 & $<0.001$ \\
\hline
\end{tabular}

${ }^{\mathrm{a}}$ In cohort studies.

BMI, body mass index; CI, confidence interval; DM, diabetes mellitus; MR, medical records; MU, medication use.

association only existed in women. We recommend further studies of high quality be undertaken in this area.

The association between the duration of DM and bladder cancer risk has been assessed in a few studies, and inconsistent results were found. The risk of bladder cancer increased with longer DM duration in one study, ${ }^{27}$ whereas the risk was significant for DM diagnosed $>1$ year previously and decreased with increasing DM duration in a study from Taiwan. ${ }^{10}$ Our meta-analysis only found the positive association between those with DM duration of 5 years or less and bladder cancer risk. The mechanism behind these results has been proposed. Insulin has been hypothesized to be a cancer growth promoter, which could explain an increased cancer risk in adults with type $2 \mathrm{DM} .{ }^{42,43}$ As well, hyperinsulinemia has been proposed to be etiologically involved in cancer carcinogenesis. $\beta$-Cells in the pancreas may produce lower levels of endogenous insulin compared with the prediabetes state with long-term DM. ${ }^{44}$ Then the risk of bladder cancer may be expected to diminished with the duration of DM. However, it is notable that only four studies were included in the subgroup analysis. Further studies are needed to identify this association between the duration of DM and risk of bladder cancer.

Only three studies assessed the association between insulin therapy for DM and bladder cancer risk. The relation between
DM using insulin and bladder cancer was stronger when we restricted the analysis to those studies. Type-specific bladder cancer risks among patients with DM have been described in three studies, ${ }^{11,27,36}$ and our meta-analysis found association between DM and the risks of invasive bladder cancer. However, maybe there were too few studies, and this could have been due to chance. ${ }^{27}$

Our study has several potential limitations of the available data. First, DM status in most of the studies was based on selfreport, which may lead to some misclassification. However, earlier studies have shown that self-reported responses for many common chronic diseases such as DM are reliable compared with medical records. ${ }^{45}$ In the current analysis, we did not find significant different RRs between studies using medical records, medication use, or blood level as a means of DM ascertainment and using self-report data to determine DM status. Second, many studies did not distinguish between type 1 and type 2 DM. When we restricted the meta-analysis to those studies that consisted of patients with type $2 \mathrm{DM}$ only, the relationship between DM and bladder cancer risk did not significantly alter. Third, some subgroup analyses were based on only a few studies. The subgroup analyses of Asia and Europe were based on only five studies, and the results need to be interpreted with caution. Moreover, as in any other meta-analysis, there is the possibility of publication 


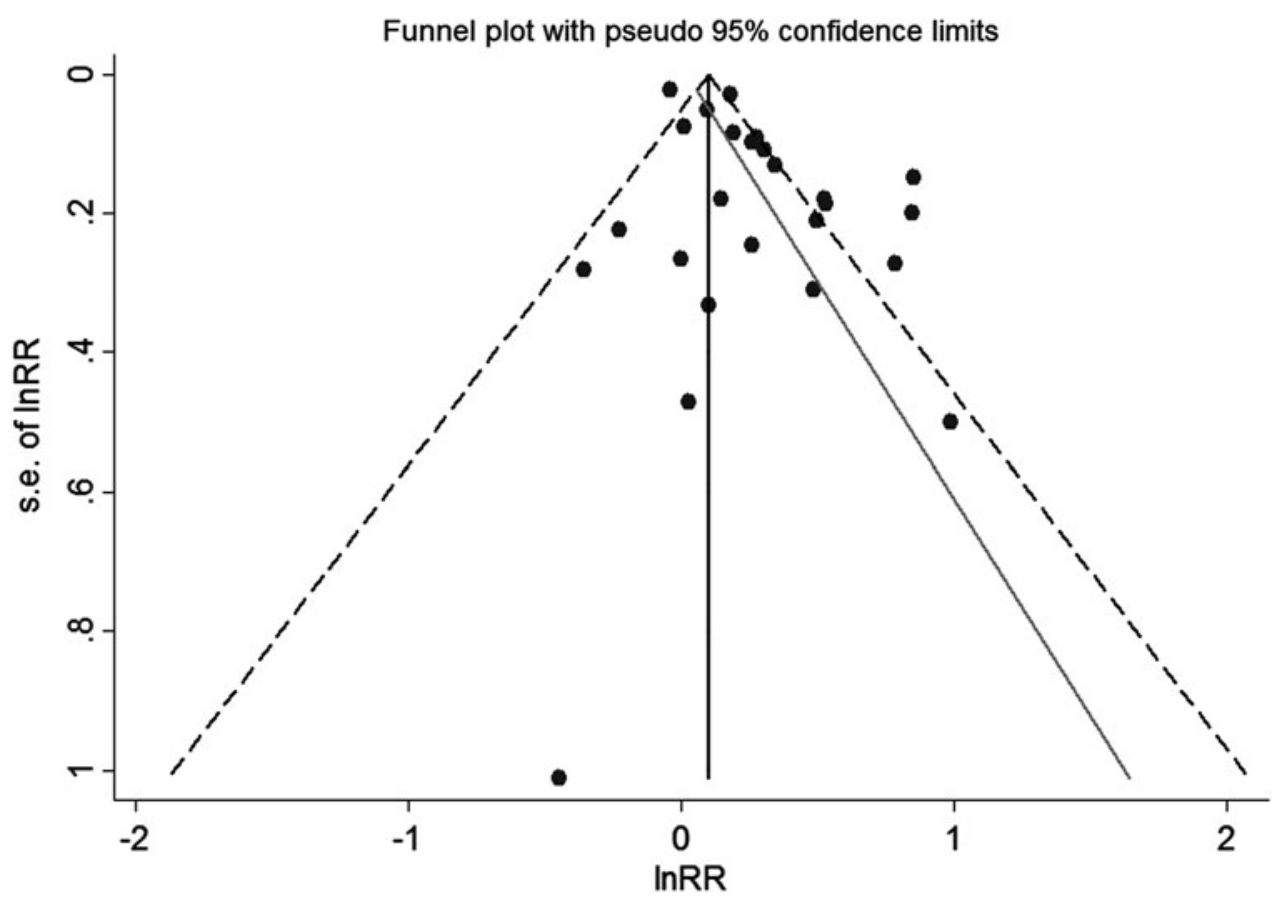

FIG. 3. Funnel plot analysis of the publication bias of the articles included about diabetes mellitus and bladder cancer. RR, relative risk.

bias because small studies with null results tend not to be published. The funnel plot showed some asymmetry, as studies with small sample sizes and low RR were missing. The presence of possible publication bias may have resulted in an overestimate of the relationship between DM and bladder cancer risk. Fourth, a limitation is methodological issue related to study design. In most cohort studies, bladder cancer ascertainment was based on cancer registry and medical records. Although nearly all the cases were histologically confirmed, reporting may be not completed, and occult cancers may not be recorded. Some misclassification of outcome is likely. Many cases in case-control studies were from hospitals or medical institutes, and these studies are susceptible to admission rate bias and prevalence-incidence bias, which could inflate the RRs. Finally, DM and bladder cancer share several risk factors that may confound the relationship. However, confounding cannot be fully excluded because our analyses were based on observational studies.

The possible mechanisms underlying the association of DM with bladder cancer risk have been inconclusive. Several possible mechanisms have been proposed, including the effects of hyperglycemia, insulin resistance, or hyperinsulinemia. ${ }^{46,47}$ However, the accumulation of experimental and epidemiological evidence is more consistent with the hyperinsulinemia hypothesis. Type $2 \mathrm{DM}$ is associated with insulin resistance and compensatory hyperinsulinemia. ${ }^{48}$ Most cancer cells express insulin receptors ${ }^{49}$; thus hyperinsulinemia could promote carcinogenesis by directly stimulating the proliferating pathway after insulin receptors. ${ }^{50}$ This hypothesis is supported by evidence that treatment with metformin, which increases insulin sensitivity and decreases hyperinsulinemia, is associated with a lower incidence of cancer in diabetes patients than in those being treated with insulin or sulfonylurea. ${ }^{51,52}$ Apart from the direct effects of insulin on cancer cells, the effects of promoting tumor cell growth may also be mediated indirectly via insulin-like growth factor (IGF)-1 receptors. Elevated insulin concentrations reduce the level of IGF-binding protein $1,53,54$ which in turn increases the amount of bioactive IGF- $1 .{ }^{55,56}$ IGF-1 has mitogenic and anti-apoptotic activities and could act as a stimulus for growing preneoplastic and neoplastic cells. ${ }^{57}$ It was suggested that patients with bladder cancer have higher plasma levels of IGF-1. ${ }^{58}$

In summary, our analysis further suggests that DM is associated with an increased risk of bladder cancer. With a worldwide increasing prevalence of DM, the incidence of bladder cancer may increase. Our findings furthermore underline the importance of preventing the emerging worldwide epidemic of DM.

\section{Author Disclosure Statement}

No competing financial interests exist.

\section{References}

1. The IDF Diabetes Atlas, $5^{\text {th }}$ ed. www.idf.org/diabetesatlas/ 5e/diabetes (accessed February 5, 2013).

2. He J, Stram DO, Kolonel LN, Henderson BE, Le Marchand L, Haiman CA: The association of diabetes with colorectal cancer risk: the Multiethnic Cohort. Br J Cancer 2010;103: 120-126.

3. Attner B, Landin-Olsson M, Lithman T, Noreen D, Olsson H: Cancer among patients with diabetes, obesity and abnormal blood lipids: a population-based register study in Sweden. Cancer Causes Control 2012;23:769-777.

4. Jee SH, Ohrr H, Sull JW, Yun JE, Ji M, Samet JM: Fasting serum glucose level and cancer risk in Korean men and women. JAMA 2005;293:194-202. 
5. U.S. Cancer Statistics Working Group: United States Cancer Statistics: 1999-2006 Incidence and Mortality Web-Based Report. Atlanta: Centers for Disease Control and Prevention, Department of Health and Human Services, and National Cancer Institute, 2010.

6. Freedman ND, Silverman DT, Hollenbeck AR, Schatzkin A, Abnet CC: Association between smoking and risk of bladder cancer among men and women. JAMA 2011;306:737-745.

7. World Cancer Research Fund, American Institute for Cancer Research: Food, Nutrition, Physical Activity and the Prevention of Cancer: A Global Perspective. Washington, DC: American Institute for Cancer Research, 2007.

8. Neumann A, Weill A, Ricordeau P, Faqot JP, Alla F, Allemand H: Pioglitazone and risk of bladder cancer among diabetic patients in France: a population-based cohort study. Diabetologia 2012;55:1953-1962.

9. Larsson SC, Orsini N, Brismar K, Wolk A: Diabetes mellitus and risk of bladder cancer: a meta-analysis. Diabetologia 2006;49:2819-2823.

10. Tseng $\mathrm{CH}$ : Diabetes and risk of bladder cancer: a study using the National Health Insurance database in Taiwan. Diabetologia 2011;54:2009-2015.

11. Larsson SC, Andersson SO, Johansson JE, Wolk A: Diabetes mellitus, body size and bladder cancer risk in a prospective study of Swedish men. Eur J Cancer 2008;44:2655-2660.

12. Zhu ZW, Zhang XH, Shen ZJ, Zhong Shan, Wang XJ, Lu YL: Diabetes mellitus and risk of bladder cancer: a metaAnalysis of cohort studies. PLOS One 2013;8:e56662.

13. Hill AB: The environment and disease: association or causation? Proc R Soc Med 1965;58:295-300.

14. DerSimonian R, Laird N: Meta-analysis in clinical trials. Control Clin Trials 1986;7:177-188.

15. Higgins JP, Thompson SG: Quantifying heterogeneity in a meta-analysis. Stat Med 2002;21:1539-1558.

16. Patsopoulos NA, Evangelou E, Ioannidis JP: Sensitivity of between-study heterogeneity in meta-analysis: proposed metrics and empirical evaluation. Int J Epidemiol 2008;37:1148-1157.

17. Egger M, Davey SG, Schneider M, Minder C: Bias in metaanalysis detected by a simple, graphical test. BMJ 1997;315: 629-634.

18. Begg CB, Mazumdar M: Operating characteristics of a rank correlation test for publication bias. Biometrics 1994;50: 1088-1101.

19. Kantor AF, Hartge P, Hoover RN, Narayana AS, Sullivan JW, Fraumeni JF Jr: Urinary tract infection and risk of bladder cancer. Am J Epidemiol 1984;119:510-515.

20. O'Mara BA, Byers T, Schoenfeld E: Diabetes mellitus and cancer risk: a multisite case-control study. J Chronic Dis 1985;38:435-441.

21. Risch HA, Burch JD, Miller AB, Hill GB, Steele R, Howe GR: Dietary factors and the incidence of cancer of the urinary bladder. Am J Epidemiol 1988;127:1179-1191.

22. La Vecchia C, Negri E, Franceschi S, D'Avanzo B, Boyle P: A case-control study of diabetes mellitus and cancer risk. Br J Cancer 1994;70:950-953.

23. Kravchick S, Gal R, Cytron S, Peled R, Weissman Y, Mukamel E, Koren R: Increased incidence of diabetes mellitus in the patients with transitional cell carcinoma of urinary bladder. Pathol Oncol Res 2001;7:56-59.

24. Ng Y, Husain I, Waterfall N: Diabetes mellitus and bladder cancer-an epidemiological relationship? Pathol Oncol Res 2003;9:30-31.

25. Rousseau MC, Parent ME, Pollak MN, Siemiatycki J: Diabetes mellitus and cancer risk in a population-based case- control study among men from Montreal, Canada. Int J Cancer 2006;118:2105-2109.

26. Jiang X, Castelao JE, Groshen S, Cortessis VK, Shibata D, Conti DV, Yuan J-M, Pike MC, Gago-Dominguez M: Urinary tract infections and reduced risk of bladder cancer in Los Angeles. Br J Cancer 2009;100:834-839.

27. MacKenzie T, Zens MS, Ferrara A, Schned A, Karagas MR: Diabetes and risk of bladder cancer: evidence from a case-control study in New England. Cancer 2011;117: 1552-1556.

28. Inoue M, Iwasaki M, Otani T, Sasazuki S, Noda M, Tsuqane $\mathrm{S}$ : Diabetes mellitus and the risk of cancer: results from a large-scale population-based cohort study in Japan. Arch Intern Med 2006;166:1871-1877.

29. Rapp K, Schroeder J, Klenk J, Ulmer H, Concin H, Diem G, Oberaigner W, Weiland SK: Fasting blood glucose and cancer risk in a cohort of more than 140,000 adults in Austria. Diabetologia 2006;49:945-952.

30. Khan M, Mori M, Fujino Y, Shibata A, Sakauchi F, Washino M, Tamakoshi A; Japan Collaborative Cohort Study Group: Site-specific cancer risk due to diabetes mellitus history: evidence from the Japan Collaborative Cohort (JACC) Study. Asian Pac J Cancer Prev 2006; 7:253-259.

31. Ogunleye AA, Ogston SA, Morris AD, Evans JM: A cohort study of the risk of cancer associated with type 2 diabetes. $\mathrm{Br}$ J Cancer 2009;101:1199-1201.

32. Yood MU, Oliveria SA, Campbell UB, Koro CE: Incidence of cancer in a population-based cohort of patients with type 2 diabetes. Diabetes Metab Syndr Clin Res Rev 2009; 3:12-16.

33. Woolcott CG, Maskarinec G, Haiman CA, Henderson BE, Kolonel LN: Diabetes and urothelial cancer risk: the Multiethnic Cohort Study. Cancer Epidemiol 2011;35:551-554.

34. Atchison EA, Gridley G, Carreon JD, Leitzmann MF, McGlynn KA: Risk of cancer in a large cohort of U.S. veterans with diabetes. Int J Cancer 2011;128:635-643.

35. Lo SF, Chang SN, Muo CH, Chen SY, Liao FY, Dee SW, Chen PC, Sung FC: Modest increase in risk of specific types of cancer types in type 2 diabetes mellitus patients. Int J Cancer 2012;132:182-188.

36. Newton CC, Gapstur SM, Campbell PT, Jacobs EJ: Type 2 diabetes mellitus, insulin-use and risk of bladder cancer in a large cohort study. Int J Cancer 2012;132:2186-2191.

37. Prizment AE, Anderson KE, Yuan JM, Folsom AR: Diabetes and risk of bladder cancer among postmenopausal women in the Iowa Women's Health Study. Cancer Causes Control 2013;24:603-608.

38. Lai GY, Park Y, Hartge P, Hollenbeck AR, Freedman ND: The association between self-reported diabetes and cancer incidence in the NIH-AARP Diet and Health Study. J Clin Endocrinol Metab 2013;98:E497-E502.

39. Tripathi A, Folsom AR, Anderson KE: Risk factors for urinary bladder carcinoma in postmenopausal women. The Iowa Women's Health Study. Cancer 2002;95:2316-2323.

40. Coughlin SS, Calle EE, Teras LR, Petrelli J, Thun MJ: Diabetes mellitus as a predictor of cancer mortality in a large cohort of US adults. Am J Epidemiol 2004;159:1160-1167.

41. Stocks T, Rapp K, Bjorge T, Manjer J, Ulmer H, Selmer R, Lukanova A, Johansen D, Concin H, Tretli S, Hallmans G, Jonsson $\mathrm{H}$, Stattin P: Blood glucose and risk of incident and fatal cancer in the Metabolic Syndrome and Cancer Project (Me-Can): analysis of six prospective cohorts. PLoS Med 2009;6:e1000201. 
42. Vigneri P, Frasca F, Sciacca L, Pandini G, Vigneri R: Diabetes and cancer. Endocr Relat Cancer 2009;16:1103-1123.

43. Vigneri R: Diabetes: diabetes therapy and cancer risk. Nat Rev Endocrinol 2009;5:651-652.

44. Bergenstal RM, Kendall DM, Franz MJ, Rubenstein AH: Management of type 2 diabetes: a systematic approach to meeting the standards of care. II: Oral agents, insulin, and management of complications. In: DeGroot LJ, Jameson JL, eds. Endocrinology, $4^{\text {th }}$ ed. Philadelphia: W.B. Saunders Co., 2001:821-835.

45. Okura Y, Urban LH, Mahoney DW, Jacobsen SJ, Rodeheffer RJ: Agreement between self-report questionnaires and medical record data was substantial for diabetes, hypertension, myocardial infarction and stroke but not for heart failure. J Clin Epidemiol 2004;57:1096-1103.

46. Johnson JA, Carstensen B, Witte D, Bowker SL, Lipscombe L, Renehan AG: Diabetes and cancer (1): evaluating the temporal relationship between type 2 diabetes and cancer incidence. Diabetologia 2012;55:1607-1618.

47. Shikata K, Ninomiya T, Kiyohara Y: Diabetes mellitus and cancer risk: review of the epidemiological evidence. Cancer Sci 2013;104:9-14.

48. Tabak AG, Jokela M, Akbaraly TN, Kivimaki M, Witte D: Trajectories of glycemia, insulin sensitivity, and insulin secretion before diagnosis of type 2 diabetes: an analysis from the Whitehall II Study. Lancet 2009;373:2215-2221.

49. Vella V, Pandini G, Sciacca L, Mineo R, Vigneri R, Pezzino $\mathrm{V}$, Belfiore A: A novel autocrine loop involving IGF-II and the insulin receptor isoform-A stimulates growth of thyroid cancer. J Clin Endocrinol Metab 2002;87:245-254.

50. Giovannucci E, Harlan DM, Archer MC, Bergenstal RM, Gapstur SM, Habel LA, Pollak M, Regensteiner JG, Yee D: Diabetes and cancer: a consensus report. Diabetes Care 2010;33:1674-1685.

51. Currie CJ, Poole CD, Gale EA: The influence of glucoselowering therapies on cancer risk in type 2 diabetes. Diabetologia 2009;52:1766-1777.
52. Libby G, Donnelly LA, Donnan PT, Alessi DR, Morris AD, Evans JM: New users of metformin are at low risk of incident cancer: a cohort study among people with type 2 diabetes. Diabetes Care 2009;32:1620-1625.

53. Ooi GT, Tseng LY, Tran MQ, Rechler MM: Insulin rapidly decreases insulin-like growth factor-binding protein-1 gene transcription in streptozotocin-diabetic rats. Mol Endocrinol 1992;6:2219-2228.

54. Powell DR, Suwanichkul A, Cubbage ML, DePaolis LA, Snuggs MB, Lee PD: Insulin inhibits transcription of the human gene for insulin-like growth factor-binding protein-1. J Biol Chem 1991;266:18868-18876.

55. Le Roith D: Seminars in medicine of the Beth Israel Deaconess Medical Center: insulin-like growth factors. N Engl J Med 1997;336:633-640.

56. Wolf I, Sadetzki S, Catane R, Karasik A, Kaufman B: Diabetes mellitus and breast cancer. Lancet Oncol 2005;6:103111.

57. Torrisi R, Mezzetti M, Johansson H, Barreca A, Pigatto F, Robertson C, Decensi A: Time course of fenretinide-induced modulation of circulating insulin-like growth factor (IGF)-I, IGF-II and IGFBP-3 in a bladder cancer chemoprevention trial. Int J Cancer 2000;87:601-605.

58. Zhao H, Grossman HB, Spitz MR, Lerner SP, Zhang K, Wu $\mathrm{X}$ : Plasma levels of insulin-like growth factor-1 and binding protein-3, and their association with bladder cancer risk. J Urol 2003;169:714-717.

Address correspondence to: Yanping Zhao, MD

Shanghai Minhang Center for Disease Control and Prevention Zhongyi Road Shanghai 201101, People's Republic of China E-mail: zhaoyanping63@yeah.net 